\title{
Arsenic exposure from drinking water and the occurrence of micro- and macrovascular complications of type 2 diabetes
}

\author{
D.D. Jovanović ${ }^{1}$, K. Paunović ${ }^{2}$, D.D. Manojlović ${ }^{3}$ \& Z. Rasic-Milutinović ${ }^{4}$ \\ ${ }^{1}$ Institute of Public Health of Serbia "Dr Milan Jovanovic Batut”, Belgrade, Serbia \\ ${ }^{2}$ Institute of Hygiene and Medical Ecology, Faculty of Medicine, University of Belgrade, Belgrade, Serbia \\ ${ }^{3}$ Institute of Chemistry, Technology and Metallurgy, Center of Chemistry, Belgrade, Serbia \\ ${ }^{4}$ Departments of Endocrinology, University Hospital Zemun, Belgrade, Serbia
}

\begin{abstract}
The highest arsenic concentrations in Serbia are measured in drinking water in the Vojvodina Region. The research was designed as a cross-sectional cohort study comprising exposed and unexposed patients with the type 2 diabetes to arsenic in drinking water in Zrenjanin municipality, Serbia. Median life time arsenic exposure from drinking water in exposed group was calculated at $181.00 \mu \mathrm{g}$ day $^{-1}$ (ranged $1.15-1369.51 \mu \mathrm{g}$ day $^{-1}$. Multivariate logistic regression model showed significantly higher odds ratio for the occurrence of myocardial infarction and stroke at arsenic concentrations above $10 \mu \mathrm{g} \mathrm{L}^{-1}$, while life time arsenic exposure significantly contributed to the occurrence of heart failure. These results support the hypothesis that exposure to arsenic in drinking water may play a role in the occurrence of micro- and macrovascular complications of type 2 diabetes.
\end{abstract}

\section{INTRODUCTION}

Arsenic is not uniquely present in waters in Serbia. Vojvodina region on the north belongs to the southern part of the Pannonian Basin, which contains high concentrations of naturally occurring arsenic (Dangic, 2007; Varsanyi and Kovacs, 2006). The highest arsenic concentrations in Serbia are measured in drinking water in the Middle Banat region within Vojvodina (Jovanović et al., 2011). Prevalence of type 2 diabetes in Serbia is approximately 600 thousand persons, or $8.2 \%$ of the total population, similarly to European prevalence (Sicree et al., 2009). The aim of this study was to explore the association between exposure to arsenic in drinking water and the occurrence of macroand microvascular complications of type 2 diabetes in Zrenjanin municipality, Serbia.

\section{METHOD}

The research was designed as a cross-sectional cohort study comprising 187 patients with type 2 diabetes divided in two groups (i.e. exposed and unexposed) according to the arsenic concentration in drinking water. The cut-off point for drinking water arsenic concentrations was the national standard of $10 \mu \mathrm{gAs}$ $\mathrm{L}^{-1}$. The research was conducted in Primary Care Center "Bosko Vrebalov" in town Zrenjanin. Each patient was undergone following measurements: body weight and height, waist and hip circumferences, blood pressure and hair arsenic concentrations. The data on age, gender, educational level, family and personal history of diabetes type 2, drinking water source and drinking water habits, smoking status, dietary habits, physical activity, as well as the level of stress were obtained through the questionnaire. In addition, data on existence and history of macro- and microvascular complications, lipid and glucose status were obtained from clinical records for each patient.

The following macrovascular complications of type 2 diabetes were included in the study: angina pectoris, myocardial infarction, chronic heart failure and stroke. Diabetic foot, retinopathy, nephropathy and poly-neuropathy were observed as microvascular complications.

Life time arsenic exposure was calculated based on daily water consumption, and arsenic concentration in drinking water, from water supplies at the current and previous places of residence.

\section{RESULTS AND DISCUSSION}

Mean arsenic concentrations in drinking water from public water supply systems in 171 waters consumed by exposed patients was $125.19 \pm 85.18 \mu \mathrm{g} \mathrm{L}^{-1}$ (median value $95.00 \mu \mathrm{g} \mathrm{L}^{-1}$, range $11.00-349.00 \mu \mathrm{g}$ $\mathrm{L}^{-1}$ ), while mean arsenic concentrations consumed by unexposed patients was $1.62 \pm 1.82 \mu \mathrm{gL}^{-1}$ (median value $1.00 \mu \mathrm{g} \mathrm{L}^{-1}$, range $0.13-10.00 \mu \mathrm{g} \mathrm{L}^{-1}$ ).

Median life time arsenic exposure from drinking water in exposed group was calculated at $181.00 \mu \mathrm{g}$ day $^{-1}$ (ranged 1.15-1369.51 $\mu \mathrm{g} \mathrm{day}^{-1}$ ). Multivariate logistic regression model was performed including age, gender, BMI, duration of diabetes, exposure to arsenic above $10 \mu \mathrm{g} \mathrm{L}^{-1}$ in drinking water and life time arsenic exposure as independent variables. This analysis showed significantly higher odds ratio for the occurrence of myocardial infarction and stroke at arsenic concentrations above $10 \mu \mathrm{gL}^{-1}$, while life time arsenic exposure significantly contributed to the occurrence of heart failure (Table 1). The same model was performed for microvascular 
Table 1. Odds ratio (95\% confidence interval) for the occurrence of macrovascular complications in relation to arsenic exposure.

\begin{tabular}{lll}
$\begin{array}{l}\text { Macrovascular } \\
\text { complications }\end{array}$ & $\begin{array}{l}\text { Exposure to arsenic } \\
\text { in drinking water }\end{array}$ & $\begin{array}{l}\text { Life time } \\
\text { arsenic exposure }\end{array}$ \\
\hline $\begin{array}{l}\text { Angina } \\
\text { pectoris }\end{array}$ & $1.004(0.517-1.950)$ & \\
$\begin{array}{l}\text { Myocardial } \\
\text { infarction }\end{array}$ & $3.817(1.322-11.020)$ & \\
$\begin{array}{l}\text { Heart failure } \\
\text { Stroke }\end{array}$ & $3.992(1.073-14.849)$ & $5.328(1.831-15.506)$ \\
\hline
\end{tabular}

Adjusted for age, gender, body mass index and duration of diabetes.

Table 2. Odds ratio ( $95 \%$ confidence interval) for the occurrence of microvascular complications in relation to arsenic exposure.

\begin{tabular}{lll}
$\begin{array}{l}\text { Microvascular } \\
\text { complications }\end{array}$ & $\begin{array}{l}\text { Exposure to arsenic } \\
\text { in drinking water }\end{array}$ & $\begin{array}{l}\text { Life time } \\
\text { arsenic exposure }\end{array}$ \\
\hline $\begin{array}{l}\text { Polyneuropathy } \\
\text { Retinopathy }\end{array}$ & $3.259(1.364-7.788)$ \\
$\begin{array}{l}\text { Nephropathy } \\
\text { Diabetic foot }\end{array}$ & $1.456(0.475-4.460)$ & $2.353(1.038-5.338)$ \\
& $5.853(1.203-28.471)$
\end{tabular}

Adjusted for age, gender, body mass index and duration of diabetes.

complications, showing significantly higher odds ratio for the occurrence of poly-neuropathy, retinopathy and diabetic foot after consumption of $181.00 \mu \mathrm{g} \mathrm{day}^{-1}$ of drinking water arsenic, calculated as life time arsenic exposure (Table 2).

A study conducted in Hungary, Romania and Slovakia reported life time arsenic dose rate of $20.8-65.6 \mu \mathrm{g} \mathrm{day}^{-1}$ for the exposed study population in Hungary (Hough et al., 2010). This is much below calculated life time arsenic exposure in our study, therefore the data on long term arsenic exposure cannot be compared between these two studies, due to different method of their calculations. The higher prevalence of microvascular and macrovascular diseases (20.0\% and $25.3 \%$, respectively) was observed in arseniasis-endemic areas for diabetics than in the nonendemic areas in Taiwan (Wang et al., 2003). One of the studies which investigated the dosedependent effect of arsenic ingestion on the prevalence of microvascular diseases, especially the kidney and nervous system, was conducted in Taiwan in 2005. It showed a dose-dependant increase in the prevalence of microvascular diseases at arsenic exposure via drinking water over $300 \mu \mathrm{g} \mathrm{L}^{-1}$ and an increasing trend in subjects who in the same time had diabetes (Chiou et al., 2005). This study also suggested that there was a higher threshold of arsenic in water for the occurrence of neuropathy $\left(\geq 600 \mu \mathrm{g} \mathrm{L}^{-1}\right)$ in healthy subjects compared to a lower threshold $\left(\geq 300 \mu \mathrm{g} \mathrm{L}^{-1}\right)$ in patients with diabetes. The results of our study indicated that significantly lover concentrations of arsenic in drinking water (around $100 \mu \mathrm{g} \mathrm{L}^{-1}$ ) may increase the risk of diabetic neuropathy, diabetic foot and retinopathy. Further investigations are needed to explore association between arsenic exposure from drinking water and the occurrence of micro- and macrovascular complications of type 2 diabetes.

\section{CONCLUSIONS}

This cross-sectional study showed that arsenic exposure from drinking water may increase risk for the occurrence of micro- and macrovascular complications of type 2 diabetes. Long term arsenic exposure from drinking water may increase risk of the occurrence of acute myocardial infarction, heart failure, stroke, diabetic foot, retinopathy and poly-neuropathy, considered as microvascular and macrovascular complications of type 2 diabetes. These results support the hypothesis that exposure to arsenic in drinking water may play a role in the occurrence of micro- and macrovascular complications of type 2 diabetes.

\section{ACKNOWLEDGEMENTS}

All authors wish to thank their collaborators in the Institute of Public Health of Zrenjanin, whose supports are greatly acknowledged.

\section{REFERENCES}

Chiou, J.-M., Wang, S.-L., Chen, C.-J., Deng, C.-R., Lin, W. \& Tai, T.-Y. 2005. Arsenic ingestion and increased microvascular disease risk: observations from the south-western arseniasis-endemic area in Taiwan. Int. J. Epidemiol. 34(4): 936-943.

Dangic, A. 2007. Arsenic in surface- and groundwater in cen-tral parts of the Balkan Peninsula (SE Europe). In: Bhattacharya, P., Mukherjee, A.B.B., Bundschuh, J., Zevenhoven, R., Loeppert, R.H. (eds). Arsenic in Soil and Groundwater Environment - Biogeochemical Interactions, Health Effects and Remediation. Elsevier, Amsterdam.

Hough, R.L., Fletcher, T., Leonardi, G.S., Goessler, W., Gnagnarella, P., Clemens, F., Gurzau, E., Koppova, K., Rudnai, P. \& Kumar, R. 2010. Lifetime exposure to arsenic in residential drinking water in Central Europe. Int. Arch. Occup. Environ. Health 83(5): 471-481.

James, K.A., Marshall, J.A., Hokanson, J.E., Meliker, J.R., Zerbe, G.O. \& Byers, T.E. 2013. A case-cohort study examining lifetime exposure to inorganic arsenic in drinking water and diabetes mellitus. Environ. Res. 123: 33-38.

Jovanović, D., Jakovljević, B., Rašić-Milutinović, Z., Paunović, K., Peković, G. \& Knezević, T. 2011. Arsenic occurrence in drinking water supply systems in ten municipalities in Vojvodina region, Serbia. Environ. Res. 111(2): 315-318.

Sicree, R., Shaw, J.E. \& Zimmet, P.Z. 2009. The global burden of diabetes. In: Gan, D. (ed). Diabetes Atlas. 4th ed. International Diabetes Federation, Brussels.

Varsanyi I. \& Kovacs, L.O. 2006. Arsenic, iron and organic matter in sediments and groundwater in the Pannonian Basin, Hungary. Appl. Geochem 21(6): 949-963.

Wang, S.-L., Chiou, J.-M., Chen, C.-J., Tseng, C.-H., Chou, W.-L., Wang, C.-C., Wu, T.-N. \& Chang, L.W. 2003. Prevalence of non-insulin-dependent diabetes mellitus and related vascular diseases in southwestern arseniasisendemic and nonendemic areas in Taiwan. Environ. Health Persp. 111(2): 155-159. 